\title{
Occurrence and Exposure to Lead and Cadmium and Their Environmental Influence on Eyesight
}

\author{
Kamil H. Nelke ${ }^{1 *}$, Małgorzata Mulak², Klaudiusz Luczak ${ }^{1}$, Wojciech Pawlak', \\ Jan Nienartowicz ${ }^{1}$, Dorota Szumny ${ }^{2,3}$, Monika Kochman ${ }^{4}$, Hanna Gerber ${ }^{1}$ \\ 'Department of Maxillo-Facial Surgery, Borowska 213, 50-556 Wroclaw \\ ${ }^{2}$ Department of Ophthalmology, Borowska 213, 50-556 Wroclaw \\ ${ }^{3}$ Department of Pharmacology, Mikulicza-Radeckiego 2, 50-345 Wroclaw \\ ${ }^{4}$ Department of Otolaryngology, Surgery of Head and Neck, Borowska 213, 50-556 Wroclaw \\ Wroclaw Medical University, Poland
}

Received: 10 February 2015

Accepted: 5 March 2015

\begin{abstract}
Nowadays heavy metals in the environment and everyday life are very common. Their usage and influence in industry is essential. Quite often not only the environment but also general human health might be impacted by their use and presence. Metal poisoning and its effect on living structures and tissues impacts their condition. The environment and every living species in it are heavily vulnerable to any heavy metal exposure and might lead to catastrophic natural disasters. In humans skin irritations and general diseases are not so common, but they do appear, and everyone should be aware of this. In this paper we focus on a very special topic related to heavy metal exposure to eyesight and their influence on this important organ. Lead and cadmium are the most common heavy metals used almost everywhere.
\end{abstract}

Keywords: heavy metal exposure, eyesight, lead, cadmium

\section{Introduction}

Heavy metal influence on the environment and humans is well known, although not all aspects are fully understood. Increased manufacturing and industrial growth without any proper approach for usage, distribution, and storage of heavy metals might lead to a very dangerous influence not only on an entire ecosphere, but also might affect human health. Because of different forms of exposure to heavy metals, different forms of after-exposure diseases might appear. Exposure by air, water, direct contact, and even by consumption - along with other less common ways of exposure - have been mentioned globally [1].

Soil and water exposed to heavy metals results in both animal and plant metal poisoning. Humans at the end of the food

*e-mail: kamil.nelke@gmail.com chain are exposed on any long- or short-term influence of heavy metal poisoning [2]. Many variables are related to poison activity on humans and the environment. Factors such as age, coexisting other diseases, and time and type of exposure are very important. Different topics are related to the environment. Type of soil, insolation, and closure to any human habitats and other factors should always be considered when discussing heavy metal exposure. Accumulation of heavy metals is dangerous for the environment. A special focus should be particularly used in order to avoid improper heavy metal disposal and increase a safe and long-term method for waste storage [3]. In order to fully understand the impact of heavy metals on humans and the environment is unlikely to improve factory production and safety standards [4].

Evaluate and describe briefly how lead and cadmium heavy metal exposure influences the sight organ and discuss whether it is a common or rare occurrence. 


\section{Metals and Sight Organ}

Many heavy metals are present in the environment. Arsenic ( $\mathrm{As})$, lead $(\mathrm{Pb})$, cadmium $(\mathrm{Cd})$, iron $(\mathrm{Fe})$, zinc $(\mathrm{Zn})$, copper $(\mathrm{Cu})$, and mercury $(\mathrm{Hg})$ are the most common. There are many possibilities for metal exposure or intoxication. Even dental materials might have components with heavy metals, and amalgam fillings are one of the most common ones. In everyday housework substances such as paint, food cans, and detergents also might have metal linings. Lead and cadmium exposure are the most common. In order to fully understand the negative impact of heavy metals for humans, types of exposure need to be noticed. Airway, alimentary canal, or skin contact might lead to various forms of exposure. In environmental studies air, water, and soil pollution are important prognostic factors for both human and environmental conditions [5].

The sight organ is the most important one in the human body. Its function and meaning is essential. A lot of factors are related to its proper function and during aging different diseases might occur. For proper organ and human body function zinc is the most wanted ion because of its influence on vision, hearing, muscle function, and immune system response. It is very important to know that if too much lead is present, then zinc levels are decreasing [6]. It's worth pointing out that different lead and cadmium levels are also present in healthy young eyes than in elderly patient's eyes with macular degeneration. In a laboratory study performed by Erie et al., excess lead in retina is related with age-related macular degeneration [7]. Even a dissection study on cadavers has shown that both lead and cadmium accumulate in human ocular tissues - especially in retinal pigment, and might be involved in eye diseases. Heavy metals accumulate in inner eye chambers, therefore it's very important to introduce this finding to any factory workers and related specialties in order to use, for example, special protective gloves and decrease potential environmental or work exposure to heavy metals.

The human body is exposed to many metal ions. A recent study made by Lansdown revealed that both skin and eyes are in constant exposure to metals [8]. Different metallic ions influence nerve fibers, the optic nerve, and the retina, which could lead to sight organ dysfunction. Optic nerves and tissues have a different susceptibility for various ions, and increased exposure might result in a threatening condition. Heavy metals and their influence on visual systems are well known, but in some cases this finding might be forgotten, and it is worth correlating environmental exposure with proper eye functions [9].

Single heavy metal intoxication might be related to different syndromes and outcomes than a combined few metals together. Rai NK et al. [10] have conducted a study dedicated to the toxicity of metals such as arsenic (As), lead $(\mathrm{Pb})$, and cadmium $(\mathrm{Cd})$. The effects of a mixture of the above-mentioned elements (in human-relevant doses) on rat astrocytes have been examined. It turns out that a metal mixture hinders white matter myelinogenesis in the optic nerve and the retina, which is relevant to retinal-cell biology. On the other hand, a study carried out by Neal et al. has proven that $\mathrm{Pb}$ exposure leads to epithelial cells and nuclei abnormalities, as well as inducing structural protein changes, which may result in lens opacity [11]. Therefore, for minimizing heavy metal ions accumulating in eye structures protective eye goggles and routine ophthalmology consultations for exposed personnel or factory workers should be scheduled.

Ugarte et al. points out that levels of iron, zinc, and copper have an effect on retinal condition. During aging different amounts of those ions are related to retinal function and degeneration [12]. Iron and zinc supplements usage might help to prevent many of those from happening; however, a different situation is present while eye structures were exposed by those metals. Direct heavy metal contact without wearing protective goggles and mask, for example, might result in a different type of visual dysfunction than exposure to metals absorbed into the blood stream.

Children, young adults, and the elderly are especially exposed to any metal pollutants that might influence their visual-motor function. Exposure from water, air, food, and other possible factors is a potential factor that might increase heavy metal toxicity, resulting in both skin or eye irritations and even a visual disability [13]. Newborns and infants using toys without any attestation that might be made from some heavy metals ions have a dangerous effect on health. It seems that not only toys but food require testing for ions causing any acquired or chronic diseases.

Since lead and cadmium are the most common ones world-wide, quite often other heavy metals also have a negative impact on human health and condition. The main factor causing negative effects, especially on the sight organ, is the type of exposure and time that expired. Cadmium, called a "silent killer," is indeed present in civilizational development and its accumulation in the environment and exposure to humans should be closely monitored [14]. Great amounts of cadmium are present in industries manufacturing high-scale batteries, fluorescent materials, paints, and nuclear reactor elements. It seems that industry and factory production is the most common cause of heavy metal poisoning affecting humans, animals, and the environment.

Industrial exposure, toxic wastes from industries and factories (especially printing, manufacturing, and different metal object production lines) are the most common occurrence sites of heavy metal poisoning. Some of those industrial wastes might leak into water sources or the ground. Factory workers exposed chronically to heavy metals quite often suffer from heavy metal exposure. The Ekinci et al. study focusing on industrial battery workers revealed that retinal nerve fiber layer thickness, macular thickness, and choroid thickness are affected; however, age, general health, and time of exposure also have a great effect on later sight organ manifestations [15].

A recent review of literature focuses on factory workers from battery factories. Both high exposure to workers and the surrounding environment was present. Yue et al. investigated topsoil samples at the factory area and concluded that soil type and texture might be greatly involved in lead distribution, which might resolve in pollution of water or deeper places of soil layers [16]. China is one of the biggest 
places for battery production in the world; therefore its pollution levels and environment related to high metal exposure is fearsome. Some factories and their adjacent environments were investigated by Chen et al. [17]. The authors confirmed that at increased distance from factories, levels of water, air, soil, trees, and human intoxication levels decrease. Also, dust with heavy metal ions was not only present but greatly influences human health and condition. Health outcomes for people living near factories are still not yet fully described. As other authors agree, the skin and eyes are the first to suffer from heavy metal contact, and when the blood stream is affected, ions wander throughout the body to different organs and structures.

A great deal of metal exposure and poisoning is related to heavy metals storage and their disposal in an ecological and safe way for both humans and the environment. Increased levels of cadmium levels in water supplies from industrial and agricultural waste are dangerous. If present in air or aerosols, they might influence eyesight because of its direct exposure to lens and eye lids [18, 19].

Factory and industrial studies are remarkable. Mulak et al. performed a study on 120 copper factory workers followed by a line of tests composed of pupil dilation, and lead and cadmium levels in full blood determination and a free erythrocyte protoporphyrin (FEP) test [20]. Lead levels were both elevated while FEP was correct. Ophthalmic evaluation showed lenticular changes in $21.7 \%$, fundus changes in $22 \%$, and episodes of other eye sensations, followed by eye redness and even changes in vision fields. Authors concluded that levels of heavy metal exposure were increased in occupationally exposed workers. This conclusion might lead to a very obvious - but still not yet fully perceptible - problem related with work factors, such as exposure protection and type of work performed being proportionally related to heavy metal exposure. Also, lack of knowledge about metal exposure and safety precautions in plant workers is worrisome.

On the other hand, cadmium exposure is more frequent for the respiratory system [21]. It is worth noticing that cadmium levels in smokers are $45 \%$ more present than in nonsmokers [22]. Also, an important deal for cadmium levels and accumulation in the human body is related to factories rather than poisoned water intake [23]. If you cumulate all three above-mentioned factors (and even others), those toxic doses of cadmium might increase to life-threatening lethal doses. Environmental accumulation of cadmium in soil and water might affect the ecosystem long-term, although longterm studies on this are not yet fully known. Perhaps increasing routine soil and water testing for exposure and accumulation would improve future environmental outcomes.

To summarize all negative issues related to heavy metal intoxication it is essential to understand what doses of lead and cadmium are poisonous for humans. Hellström et al. concluded that for people close to a battery plant or factory, levels of heavy metals concentration in soil and moss could be a good diagnostic measuring tool [24]. Environmental exposure is measured by air, water, and soil pollution. The human exposure rate is more complicated because of related factors.
Water pollution and the great amount of seafood exposure to heavy metals are worrisome. Fillion et al. investigated ocular pathologies in 243 habitants of Pará State in Brazil who were under the influence of a seafood diet containing $\mathrm{Hg}$ and $\mathrm{Pb}$. Ocular findings revealed that the presence of $\mathrm{Hg}$ and $\mathrm{Pb}$ might increase the risk for visual acuity in older persons. However, loss of visual acuity during ageing is also diet-related, and consumption of n-3 fatty acids and Se has positive effects on eyesight [25]. Similar seafood studies lack information about direct lead and cadmium effects on the sight organ.

Wastes from industry and heavy metal residue present in the environment are causing long-term effects on both humans and the ecosystem. Depending on location, heavy metals concentrations from industry can greatly influence many aspects of life. In order to measure heavy metals concentrations ( $\mathrm{Cd}, \mathrm{Pb}, \mathrm{Cu}, \mathrm{Zn}$, and $\mathrm{Ni}$ ) in foodstuffs, house dust, drinking water, and soil near electronic waste deposits in China, Zheng et al. concluded that drinking water had fewer levels of heavy metals than others. Authors conclude that oral intake of heavy metals, especially $\mathrm{Pb}$, has a greater cancer-inducing potential. Contacts with heavy metals during inhalation and direct skin contact has fewer negative effects, but smaller children are at great risk of increased heavy metal exposure when exposed to house dust [26].

Heavy metal ions are also quite common in leathermanufacturing facilities. At high risk of metal poisoning are groundwaters near the factories. The Dwivedi and Vankar study concludes that groundwater should be closely routinely monitored for any increased or suspicious metal content, which could be very important in order to decrease potential heavy metal poisoning in the future [27]. Also, ground waters and mineral water sources should be tested.

A lot of world studies concerning heavy metals exposure and risks are made in China. According to some studies, not only industrial waste and manufacturing is a source of heavy metal exposure but also heavy traffic, lack of adequate protective appliance in industries, and close proximity of agricultural areas near various factories. Liu et al. studied 268 vegetable samples and concluded that both vegetables and corresponding soils has significantly elevated $\mathrm{Pb}$ and $\mathrm{Cd}$ levels, along with other elements. However, increased $\mathrm{Cd}$ levels have more carcinogenic potential than $\mathrm{Pb}$. The authors concluded that food with high heavy metal content is dangerous, and that more control studies and increased safety approaches should be carried out [28].

Soil, plants and animals are quite often affected by heavy metal poisoning, ion residue, or even because of toxic dump storage. A huge difference is when a local water or underground water supply is contaminated with heavy metals, which in turn influences plant growth and different aspects of wastewater use, which shouldn't be used for irrigation purposes [29]. In some cases heavy metals accumulate in rivers [30].

It seems that regional water poisoning caused by arsenic, manganese, and lead are the most studied ones. While water poisoning is well known and studied, the influence of heavy metals accumulation in plants and fish and their ways of consumption by humans still lacks long-term outcomes and 
results. Environmental studies focused on water poisoning also lead to very important conclusions. A mixture of arsenic, lead, and cadmium in water might be resolved in a mixture formation that has huge myelin disintegration in the central nervous system, causing optic nerve and retina disease. The authors have concluded that the time and exposure factor is not favorable for axon and myelin-fibers condition. Also, nerve-fiber thickness, retinal health, and axon condition might be important prognostic factors for clinicians [31]. If heavy metals do cumulate in water, not only sea plants but also fish are exposed to dangerous levels of ions. Allen investigated a fish Oreochromis aureus (Steindachner) and concluded that accumulation of heavy metal ions in fish tissues available is dangerous for consumption for humans and agricultural animals. Therefore, fish breeding ponds near factories or close to any factory sludge should be always be subjected to serious examination [32].

Quite often not only water but also soil can be affected by heavy metals. In a study conducted by Wang et al., levels of $\mathrm{Zn}, \mathrm{Cd}$, and $\mathrm{Pb}$ of used phosphorus and as $\mathrm{KH}_{2} \mathrm{PO}_{4}$ decreased the phototoxicity in contaminated soil. It seems that clearing heavy metals ions from soil could be achieved [33].

Levels of heavy metals accumulation in different soil types might influence various plant growth, shape, and consumption purposes. In a study performed by Hashemi et al., plant growth in two different examined places was different. Length of root, shape, and size of the plant were different in the area with high levels of heavy metals [34]. When plants are under the influence of heavy metals their physiology is changed. Heavy metals affect plant seeds and the germination process, but the type of metal and time of exposure are important [35]. The great danger to ecosystems and agriculture is worrisome.

A serious problem of potential heavy metal poisoning is use of daily objects that could have a higher dose of ions than they should have. Fruits and vegetables grown in various soils with ions of heavy metals present might lead to food intoxication. Christou et al. performed a study on orange orchards and evaluated soil geochemical properties and accumulation of heavy metals. It seems that fruits and vegetables that are growing on a soil with increased amounts of heavy metal ions are behaving quite similarly to those affected by air pollution and fumes, but significant changes in agricultural product values have been seen [36, 37].

It seems that heavy metals present as cigarette fillings and in smoke can easily penetrate into the aero-digestive system and also the sight organ. Cekic correlated cigarette smoking and cadmium accumulation in the lens and concluded that nicotine and additional fillers from cigarettes might have additional heavy metals ions, and smoking might be cataractogenic [38]. The deposition of various ions in the lenticule might be different in both genders, or might result in cataract morbidity [39]. Again, for further understanding ionic impact on organisms and the environment, many studies need yet be performed. Animal and human studies have revealed a few interesting facts. Studies made on rabbits fed with high doses of cadmium revealed that eye concentration of this metal leads to retinopathy and even corneal damage $[40,41]$.
In some cases other heavy metal ions are present in cosmetics or some daily used merchandise. Mercury poisoning also affects retinal and optic nerve functions [42].

Additional metal substitutes of many cosmetics also is dangerous. Amry et al. reported a case where eyeliner caused severe corneal edema and faint scarring. Further investigation revealed increased levels of lead (307,562,348 ppm) and cadmium (6,259 ppm) [43]. Because of heavy metals characteristics and easy use in different types of everyday life items, increased testing should be performed, especially on those items remaining in close proximity to skin and eyes.

\section{Conclusions}

Heavy metals are a great threat to the environment and human health. In order to maintain a low presence of intoxication and metal exposure, more adequate prophylactic steps should be made. More frequent routine heavy metal testing should be performed in factories and adjacent areas. Air, soil, and water pollution measurements should be performed. Another step in order to avoid visual symptoms of heavy metal intoxication is increasing people's knowledge and awareness of heavy metal exposure and potential patterns of exposure. Not only local farmers but also factory workers should be aware. In order to avoid direct heavy metal contact, protective gear such as goggles, masks, and gloves should be used. In long-term factory workers routine blood panel testing and visual sight accuracy should be made. Production lines and inadequate worker performance during production might greatly increase their visual organ and heavy metals exposure. Although cadmium and lead exposure are not so common, they are the most frequent especially in regions with increased industrial and factory occupancy. Minimizing cadmium and lead levels used for production might greatly influence human well-being and improve the environment. Furthermore, people's knowledge and awareness of heavy metals' negative impact on health and the environment should be improved.

\section{Acknowledgements}

The authors report no conflicts of interest.

This article required no approval from an institutional committee because it is not directly related to human care and to treatment of animals used in study.

Investigation has been conducted in accordance with ethical standards, the Declaration of Helsinki, and national and international guidelines.

\section{References}

1. CINNIRELLA S., HEDGECOCK I.M., SPROVIERI F. Heavy metals in the environment: sources, interactions and human health. Environ. Sci. Pollut R. 21, (6), 3997, 2014.

2. ZHENG J., HUYNH T., GASPARON M., NG J., NOLLER B. Human health risk assessment of lead from 
mining activities at semi-arid locations in the context of total lead exposure. Environ. Sci. Pollut R.. 20, (12), 8404, 2013.

3. WOJCIECHOWSKA E., GAJEWSKA M. Partitioning of heavy metals in sub-surface flow treatment wetlands receiving high-strength wastewater. Water. Sci. Technol. 68, (2), 486, 2013 [In Polish].

4. BALTRĖNAITÉ E., BALTRĖNAS P., LIETUVNINKAS A., SEREVIČIENÉ V., ZUOKAITÉ E. Integrated evaluation of aerogenic pollution by air-transported heavy metals $(\mathrm{Pb}, \mathrm{Cd}, \mathrm{Ni}, \mathrm{Zn}, \mathrm{Mn}$ and $\mathrm{Cu})$ in the analysis of the main deposit media. Environ. Sci. Pollut R. 21, (1), 299, 2014.

5. SITAREK K., SZADKOWSKA-STAŃCZYK I., SZYMCZAK W. Cadmium and its compounds. Guidelines estimating carcinogens health risk factors. T.3. IMP, Łódź, pp 67-106, 1996 [In Polish].

6. ERIE J.C., GOOD J.A., BUTZ J.A. Excess lead in the neural retina in age-related macular degeneration. Am. J. Ophthalmol. 148, (6), 890, 2009.

7. ERIE J.C., BUTZ J.A., GOOD J.A., ERIE E.A., BURRITT M.F., CAMERON J.D. Heavy metal concentrations in human eyes. Am. J. Ophthalmol. 139, (5), 888, 2005.

8. LANSDOWN A.B. Metal ions affecting the skin and eyes. Met. Ions. Life. Sci. 8, 187, 2011.

9. MULAK M. The effect of heavy metals (lead, cadmium, and manganese) on the function of the visual system. Med. Pr. 49, (6), 603, 1998 [In Polish].

10. RAII N.K., ASHOK A., RAI A., TRIPATHI S., NAGAR G.K., MITRA K., BANDYOPADHYAY S. Exposure to As, $\mathrm{Cd}$ and $\mathrm{Pb}$-mixture impairs myelin and axon development in rat brain, optic nerve and retina. Toxicol. Appl. Pharm. 1, 273, (2), 242, 2013

11. NEAL R.E., LIN C., ISOM R., VAISHAV K., ZIGLER J.S. $\mathrm{JR}$. Opacification of lenses cultured in the presence of $\mathrm{Pb}$. Mol. Vis. 16, 2137, 2010.

12. UGARTE M., OSBORNE N.N., BROWN L.A., BISHOP P.N. Iron, zinc, and copper in retinal physiology and disease. Surv. Ophthalmol. 58, (6), 585, 2013.

13. MARLOWE M., STELLERN J., ERRERA J., MOON C. Main and interaction effects of metal pollutants on visualmotor performance. Arch. Environ. Health. 40, (4), 221, 1985.

14. KRZYWY I., KRZYWY E., PEREGUD-POGORZELSKI J., ŁUKSZA K., BRODKIEWICZ A. Cadmium - is there something to fear? Ann. Acad. Med. Stett, 5, (7), 49, 2011 [In Polish].

15. EKINCI M., CEYLAN E., CAĞATAY H.H., KELEŞ S., ALTINKAYNAK H., KARTAL B., KOBAN Y., HÜSEYINOĞLU N. Occupational Exposure to Lead Decreases Macular, Choroidal, and Retinal Nerve Fiber Layer Thickness in Industrial Battery Workers. Curr. Eye Res. 39, (8), 853, 2014

16. YUE X., SUN T.C., HUANG J.L. Distribution characteristics of lead in different particle size fractions of surface soil of a lead-acid battery factorycontaminated site. Huan. Jing. Ke. Xue. 34, (9), 3679, 2013.

17. CHEN L., XU Z., LIU M., HUANG Y., FAN R., SU Y., HU G., PENG X., PENG X. Lead exposure assessment from study near a lead-acid battery factory in China. Sci. Total. Environ. 429, 191, 2012.

18. OSTROWSKA P. Cadmium - occurrence, sources of pollution, recycling methods. Gospodarka Surowcami Mineralnymi. 24, 255, 2008 [In Polish].

19. MUSTAFA H.T., HASSAN H.M., ABO-MELHA A., RIHAN T.I. Cadmium and zinc concentrations in the potable water of the Eastern Province of Saudi Arabia. B. Environ. Contam. Tox. 40, 462, 1988.
20. MULAK M., MISIUK-HOJŁO M., MARKUSZEWSKIN B., DEMBSKA K. Influence of chronic exposure to heavy metals on eyesight. Klin. Oczna. 4-6, 176, 2008 [In Polish].

21. SATARUG S., MOORE M.R. Adverse health effects of chronic exposure to low-level cadmium in foodstuffs and cigarette smoke. Environ. Health Persp. 112, 1099, 2004.

22. BONDA E., WŁOSTOWSKI T., KRASOWSKA A. Metabolism and toxicity of cadmium in humans and animals. Kosmos. 56, 87, 2007 [In Polish].

23. BLAZKA M.E., SHAIKH Z.A. Sex differences in hepatic and renal cadmium accumulation and metallothionein induction. Role of estradiol. Biochem. Pharmacol. 41, 775, 1991.

24. HELLSTRÖM L., JÄRUP L., PERSSON B., AXELSON O. Using environmental concentrations of cadmium and lead to assess human exposure and dose. J. Expo. Anal. Env. Epid. 14, (5), 416, 2004.

25. FILLION M., LEMIRE M., PHILIBERT A., FRENETTE B., WEILER H.A., DEGUIRE J.R., GUIMARÃES J.R., LARRIBE F., BARBOSA F. JR, MERGLER D. Visual acuity in fish consumers of the Brazilian Amazon: risks and benefits from local diet. Public. Health. Nutr. 14, (12), 2236, 2011.

26. ZHENG J., CHEN K.H., YAN X., CHEN S.J., HU G.C., PENG X.W., YUAN J.G., MAI B.X., YANG Z.Y. Heavy metals in food, house dust, and water from an e-waste recycling area in South China and the potential risk to human health. Ecotox. Environ. Safe. 96, 205, 2013.

27. DWIVEDI A.K., VANKAR P.S. Source identification study of heavy metal contamination in the industrial hub of Unnao, India. Environ. Monit. Assess. 186, (6), 3531, 2014.

28. LIU X., SONG Q., TANG Y., LI W., XU J., WU J., WANG F., BROOKES P.C. Human health risk assessment of heavy metals in soil-vegetable system: a multi-medium analysis. Sci. Total. Environ. 463, 530, 2013.

29. ACKAH M., ANIM A.K., GYAMFI E.T., ZAKARIA N., HANSON J., TULASI D., ENTI-BROWN S., SAAHNYARKO E., BENTIL N.O., OSEI J. Uptake of heavy metals by some edible vegetables irrigated using wastewater: a preliminary study in Accra, Ghana. Environ. Monit. Assess. 186, (1), 621, 2014.

30. GAO B., ZHOU H., LIANG X., TU X. Cd isotopes as a potential source tracer of metal pollution in river sediments. Environ. Pollut. 181, 340, 2013.

31. RAI N.K., ASHOK A., RAI A., TRIPATHI S., NAGAR G.K., MITRA K., BANDYOPADHYAY S. Exposure to As, $\mathrm{Cd}$ and $\mathrm{Pb}$-mixture impairs myelin and axon development in rat brain, optic nerve and retina. Toxicol Appl Pharm. 273, (2), 242, 2013.

32. ALLEN P. Long-term mercury accumulation in the presence of cadmium and lead in Oreochromis aureus (Steindachner). J. Environ. Sci. Heal. B. 30, (4), 549, 1995.

33. WANG B.L., XIE Z.M. Effects of phosphorus application on translocation of lead, zinc and cadmium in the soil-plant system. Huan. Jing. Ke. Xue. 29, (11), 3225, 2008.

34. HASHEMI S.A., FARAJPOUR G. Investigation of cadmium pollution in the spruce saplings near the metal production factory. Toxicol. Ind. Health. 2013 [In Print].

35. SETHY S.K., GHOSH S. Effect of heavy metals on germination of seeds. J. Nat. Sci. Biol. Med. 4, (2), 272, 2013.

36. CHRISTOU A., ELIADOU E., MICHAEL C., HAPESHI E., FATTA-KASSINOS D. Assessment of long-term wastewater irrigation impacts on the soil geochemical properties and the bioaccumulation of heavy metals to the agricultural products. Environ. Monit. Assess. 186, (8), 4857, 2014. 
37. GARAU G., SILVETTI M., CASTALDI P., MELE E., DEIANA P., DEIANA S. Stabilising metal(loid)s in soil with iron and aluminium-based products: Microbial, biochemical and plant growth impact. J. Environ. Manage. 139, 146, 2014.

38. CEKIC O. Effect of cigarette smoking on copper, lead, and cadmium accumulation in human lens. Brit. J. Ophthalmol. 82, (2), 186, 1998.

39. CEKIC O. Copper, lead, cadmium and calcium in cataractous lenses. Ophthalmic. Res. 30, (1), 49, 1998.

40. GRUBB B.R., DUVAL G.E., MORRIS J.S., BENTLEY P.J. Accumulation of cadmium by the eye with special reference to the lens. Toxicol. Appl. Pharm. 77, 444, 1985.
41. PROST M., GERKOWICZ K. Experimental studies on cadmium accumulation in eye structures. Klin. Oczna. 88, 330, 1986 [In Polish].

42. IABLONSKAIA D. A., MISHCHENKO T. S., LAKHMAN O. L., RUKAVISHNIKOV V. S., MALYSHEV V. V. Functional state of vision system under chronic mercury intoxication. Med. Tr. Prom. Ekol. 10, 40, 2010.

43. AMRY M.A., AL-SAIKHAN F., AYOUBI A. Toxic effect of Cadmium found in eyeliner to the eye of a 21 year old Saudi woman: A case report. Saudi. Pharm. J. 19, (4), 269, 2011. 